\title{
The Transmission of the Revolutionary Spirit: Reflections on Civil Disobedience in Hannah Arendt*
}

\author{
Stefania Fantauzzi \\ $\mathrm{PhD}$, Reseacher, Philosophy and Gender Seminar, University of Barcelona \\ Address: Montalegre, 6, Barcelona, Spain 08001 \\ E-mail: stefantauzzi@gmail.com
}

\begin{abstract}
The aim of this paper is to take up Hannah Arendt's analysis on civil disobedience. This is one aspect of Arendt's thought which represents a powerful spur towards a positive and meaningful view of the world we live in. In taking up this argument I start from Arendt's idea of the law, discussing its relational dimension and its links to the consensus universalis, seen as a conscious, wholehearted adhesion to the laws of a country. Bearing these two points in mind, I then consider Arendt's proposal, put forward in her essay "Civil Disobedience," for making the spirit of the law compatible with civil disobedience. The idea that civil disobedience is compatible with the spirit of the law represents, for Arendt, the acknowledgement of the community's constitutive function, in which individuals define themselves in their relationships with others, drawing on a type of justice which emerges from the encounter of differing opinions. From this perspective, I explain how civil disobedience allows citizens to assert their public freedom, thereby adding something new to the world and exercising their responsibility. Thus for Arendt civil disobedience reaffirms the creation, also fostered by the revolutionary spirit, of a space of permanent participation in public life: a shared arena for the enjoyment of public happiness.
\end{abstract}

Keywords: Arendt, civil disobedience, revolution, consensus universalis, law, transmission

This essay examines one aspect of Hannah Arendt's thought which can be enormously fruitful for our attempts to interpret the world we currently live in: her ideas on civil disobedience. The questions of what the law actually is, what margins of freedom it leaves the individual and if we may legitimately oppose it are clearly of compelling relevance to today's world.

In discussing these issues I set out from the Arendtian concept of the law, bringing out its relational dimension and its ties to the consensus universalis, which Arendt sees as the conscious and comprehensive adherence to the laws of a particular country. Bearing these two points in mind, I then move on to the idea that civil disobedience can be made compatible with the spirit of the law, as put forward by Arendt in her essay "Civil Disobedience." Accepting this compatibility for her means that the constitutive function of the community is explicitly acknowledged: individuals define themselves through their relationships with others and justice takes shape through the mutual encounter of di-

\footnotetext{
(C) Stefania Fantauzzi, 2018

(C) Centre for Fundamental Sociology, 2018

DOI: $10.17323 / 1728-192 \mathrm{X}-2018-4-131-143$

* This article was written as part of the research project titled "Transmission in Women's Philosophical Thought" (TRAFILO, FFI-2015-63828-P, MINECO/FEDER, UE).
} 
vergent opinions. Subsequently, I explain how this possibility incorporates the spirit of revolution, seen by Arendt as the aspiration to public freedom and happiness and the realization of the public spirit.

\section{The Concept of the Law in Hannah Arendt's Political Philosophy}

In all Arendt's works we find a constant concern with the fragility of human action, stemming from the tendency of action itself "to force open all limitations and cut across all boundaries" (Arendt, 1958: 190) and from its unforeseeable and irreversible nature. In Arendt the celebration of the human ability to create new beginnings is interwoven with the need to trace political limits to guarantee lasting stability in the public sphere. In this context it is the law, according to Arendt, that makes the achievement of this stability possible. She writes: "The variety of such systems is great, both in time and space, but they all have one thing in common - the thing than justifies us in using the same word for phenomena as different as the Roman lex, the Greek nomos, the Hebrew torah - and this is that they were designed to insure stability" (Arendt, 1972a: 79). For Arendt, the law finds its raison dêtre in its power to organize the political sphere, laying down the limits of the latter and ensuring communication amongst a community that is constantly dealing with the new beginnings represented by the birth of each and every human being. For her the function of the law is neither to discipline nor punish but to safeguard the ties forged between people who live together in a community. The Arendtian view of the law, therefore, is directly opposed to that of the Western political tradition, which embodies and entrenches the belief that collective action is only a question of who issues the orders and who obeys them. From this perspective the law is interpreted in terms of command and obedience and assimilates coercion, which, in the final analysis, becomes the base of the political edifice, essentially seen as one of domination. This top-down vision of the law is reinforced by the Judeo-Christian idea of divinely inspired writ, stemming from an "almost automatic generalization of God's Commandments, according to which the simple relation of command and obedience ... sufficed to identify the essence of law" (Arendt, 1969: 138). According to Arendt this Judeo-Christian ideology of the law is significant not only because it is based on the relations between rulers and the ruled, but also in its appeal to a transcendent origin beyond all human power (Arendt, 1963: 189): a Creator or Divine Legislator who fashions the law and identifies its authority with the coercive, irresistible force with which transgression is punished. This view of the law is intimately linked to the concept of a creative power which expresses itself, in the last analysis, in violence. Historically, the consolidation of the Catholic Church's dominion ensured the definitive prevalence of this model of the law (Arendt, 1963: 189-190). When the Church's authority waned with the process of secularization in the modern era, it became necessary to find a new source of the law's authority. Thus Bodin and Hobbes located the sources of all earthly power in the sovereignty of the absolute monarch, while the French Revolution saw it in the will of the nation and 2oth-century totalitarianism in Nature and History. For Arendt this transference of absolute, divine authority to the 
human sphere brings serious consequences, since it involves the duty to punish whoever opposes the sovereign or the will of the nation and ultimately leads to the justification of oppression and terror as legitimate political tools (Arendt, 1951: 461-467).

In Arendt's view "the common dilemma - either the law is absolutely valid and therefore needs for its legitimacy an immortal, divine legislator, or the law is simply a command with nothing behind it but the state's monopoly of violence - is a delusion" (Arendt, 1969: 193). To solve this "common dilemma" she develops a new concept of power, drawing on alternative models of the law.

We should start out by clarifying that Arendt opposes the idea of power as the basis of the law. In her writings of the 1950 s she elaborates the concept of a form of power contrasting almost the entire tradition of Western political thought. This new concept is based on the notion of potentiality, which she sees as intrinsically linked to power. "The word itself, its Greek equivalent dynamis, like the Latin potentia with its various modern derivatives or the German Macht (which derives from mogen and moglich, not from machen), indicates its 'potential' character" (Arendt, 1958: 200). Recognizing this meaning enables us to distinguish power from other concepts traditionally associated with it, such as force or domination; and this is a distinction which links back to the idea of political experience as the possibility of people gathering and acting in concert which characterizes all Arendt's thought.

It is in this sense that Arendt opposes the identification of power as the basis of the law. In her view we should instead see the law as a bulwark and a limit which power should never overstep. If power is seen as a tool for applying the law, then it becomes a necessary evil; if however the law is seen as a check on power, then the law owes its existence only to this vital function of restraint, and power becomes a positive force, one which is both "free and good" (Arendt, 1995: 94).

The innovation that power brings and which springs from action should therefore be balanced by the stability of legislation based on a constitution. The role of such legislation, however, is not to impose a positive order on the political sphere, nor to steer action, but rather to limit it, tempering its inherent unpredictability and guaranteeing lasting freedom. This means that the law can limit change, but cannot initiate changes; it can regulate the political sphere, but cannot prescribe any part of it.

By thus conceiving the law as a limit we go back to the ancient meaning of the nomos, put in place by people to protect and delimit a fragile and precious good: the citizens' own actions. For the Greeks, laying down a law was a pre-political action made by a legislator whose task was to fix the limits within which people could live freely, and in consequence it had no value outside the polis itself. Clearly therefore the nomos had an intrinsically spatial, local value, on the basis of which city-states could multiply by settling new colonies but could never forge lasting links with each other. We should add that the law, for the Greeks, took form in the sphere of making, since the legislator was more a specialized craftsman or architect than citizen or statesman, and expressly fashioned the features of the law to fit the political arena (Arendt, 1958: 63-64). This view, however, locates the law outside the sphere of action, since it lacks a relational dimension; a dimension which, in 
Arendt's view, was present in the Roman concept of the law, inextricably bound up with plurality.

This is a concept which takes us back to the original meaning of the word lex, referring to the tie between two people or things brought together by circumstance (Arendt, 1958: 183-184). The existence of a people as an ethnic and organic unit was for the Romans independent from the presence of legislation; only after Aeneas' arrival in Italy and the outbreak of war between the newcomers and the local people was the need to lay down laws felt. Through these laws a new unity was constituted between two deeply differing entities who, after confronting each other in battle, had finally opted to merge (Arendt, 1951: 187). The law, then, has no need of an absolute source: it creates new relationships among people and unites them not through natural rights or commandments imposed from without on all alike, but through an agreement between consenting partners. Differently to the nomos, which is conceived by a legislator and precedes the birth of politics, lex stems from a "back and forth exchange of words and actions" (Arendt, 2005: 180). The difference between the Greek and Roman concepts of the law can also be explained by recalling that the Roman people had been able to move forward through the alliances created after the struggles between patricians and plebeians, brought to an end with the promulgation of the Law of the Twelve Tables: a contract between two rival factions requiring the consensus of all the people: a consensus universalis which takes pride of place in Roman historiography (Ibid.: 185-186).

\section{The consensus universalis}

According to Arendt the idea of the consensus universalis is fundamental, since it regards the citizens' position in relation to the law, as she explains in the essay "Civil Disobedience," discussing the situation in the USA at the end of the 1960 s and in the 1970s. During this period the country was going through a deep crisis, whose main elements Arendt analyses in "Lying in Politics" (Arendt, 1972b: 3-47), written shortly after "Civil Disobedience," and in numerous letters to her friend Mary McCarthy ${ }^{1}$. On many occasions the US government flirted with illegality and breaching the constitution: the seven years of undeclared war in Vietnam; the growing influence of the secret services on public affairs; the naked or barely concealed threats to the fundamental freedoms guaranteed by the First Amendment; and the attempts to deprive the Senate of its constitutional prerogatives, such as Nixon's decision to invade Cambodia, in flagrant contradiction of the Constitution, which explicitly requires the approval of Congress for acts of war (Arendt, 1972a: 74-75).

In "Civil Disobedience," Arendt recalls that in modern constitutions the sovereign is such only when represented, but at the same time representation happens only by channeling sovereign power towards the top and depoliticization towards the bottom: in this way the reductio ad unum of the represented individuals, bound together in the people,

1. In a letter of 19th May 1969 for example, Arendt writes: "Here everything goes from bad to worse. It looks like the end of the Republic, though not necessarily of the country" (Arendt, McCarthy, 1995: 235). 
the nation, the state, is realized. Thus the decisions of the represented subject are not free, since representation breaks the direct link between liberty and popular will, interposing the mediation of the representative institutions. In this way political action is transformed into administrative technique. We find examples of this model throughout the Western tradition of political philosophy, whether in the liberal tendency of Hobbes or in the democratic one of Rousseau: once all power is concentrated in the hands of the sovereign by means of the social contract, the entire society is deprived of political power.

Through this argument Arendt criticizes the social contract as a vertical pact, to which she then counters the idea of a horizontal contract. Aside from the Biblical bond established by a people with their god, Arendt discusses firstly the Hobbesian contract, in which each individual enters into an agreement with the sovereign, thereby renouncing his or her rights and powers in return for a guarantee of security. To this she contrasts the horizontal contract put forward by Locke, where instead individuals come together to form a community founded on equality and reciprocity: in this way, while limiting the power of its individual members, the community's collective power is left intact, and it can set up a government founded on a contract between independent persons. While all contracts, pacts and agreements presuppose relations of reciprocity, the great advantage of this horizontal social contract is that every citizen remains bonded to every other through this relationship. It is the only form of government in which the link between individuals is based neither on a common history or ethnic homogeneity, as in the nationstate, nor on a tie such as in Hobbes' Leviathan, which unites the people by oppressing them. The horizontal contract hinges on the strength of the mutual endeavor to create public arenas in which freedom and action can be exercised (Arendt, 1972a: 85-87).

Arendt recalls that agreements and promises are the only tools with which individuals can organize and settle their future, thus making it as foreseeable as possible. However, since the future can never be completely predictable, we are only held to respect our agreements if unforeseen events do not intervene and reciprocity is not broken. In the USA of the 1960s and 1970s the government's frequent challenges to the Constitution and the people's resulting loss of faith in constitutional power seem to have led to the need to set up a new consensus that would renew the consensus universalis previously granted to the Constitution and constitute the spirit of American law itself (Ibid.: 84-89).

Arendt goes on to say that the consensus universalis is based on a tacit adhesion which cannot be seen as voluntary if the possibility of dissent is not contained within it. She presents consensus universalis as a conscious and comprehensive adhesion to the laws of a country and as being fully realized only when dissent and dispute are recognized as prerequisites of a truly free country:

We all live and survive by a kind of tacit consent, which, however, it would be difficult to call voluntary. How can we will what is there anyhow? We might call it voluntary, though, when the child happens to be born into a community in which dissent is also a legal and de facto possibility once he has grown into a man. Dissent implies consent, and is the hallmark of free government; one who knows that he may dissent knows also that he somehow consents when he does not dissent. 
Consent as it is implied in the right to dissent - the spirit of American law and the quintessence of American government - spells out and articulates the tacit consent given in exchange for the community's tacit welcome of new arrivals, of the inner immigration through which it constantly renews itself. (Ibid.: 88)

At this point the problem arises of how civil disobedience may be compatible with the spirit of the law. In fact, Arendt gives paramount importance to the discovery of a formula which can constitutionalize civil disobedience: the law's recognition of it, according to her, represents a huge advance in the relationship between the state and its citizens and can determine whether its institutions are flexible enough to stand up to the assaults it is subject to without falling into civil war or revolution.

If we look at civil disobedience from the juridical point of view it inevitably appears as a disruption of legality: a law cannot justify its own violation even when it has the object of preventing the violation of another law. However, knowing whether there is at least a possibility of making a place for civil disobedience in our political institutions is another question, which involves addressing the issue of duty and obligation in the political sphere; and this means going back to the right to criticize any law that is not seen to fit with collective aspirations, and any government undertaking legally and constitutionally dubious actions. Thus we can affirm that civil disobedience has its roots in the concept of justice as a public good.

\section{Civil Disobedience}

For Arendt, then, civil disobedience represents the recognition of the constitutive function of a community which defines each of its individual members in relation to all others; and is rooted in the concept of justice as shaped by the mutual encounter of differing opinions. In her view, "justice is the essence of men's living together" (Arendt, 1994: 325). Appealing to this idea of justice, civil disobedience involves the power of openly declaring the injustice of specific laws and opposing them, aspiring, in this way, to reduce the prescriptive nature of the law. We should not forget that, as we saw previously, the purpose of the law and of the institutions as a whole is only to check the shifts and changes resulting from individuals' free, innovative actions. Thus the law cannot itself drive transformation: it "can indeed stabilize and legalize change once it has occurred, but that change itself is always the result of extra-legal action" (Arendt, 1972a: 80).

This discussion implies, therefore, that if the legitimacy of civil disobedience were recognized juridically then the relationship between the state and the citizen would take a huge leap forward, since within it the free action of the individual even against the institutions themselves would be guaranteed, thereby addressing the issues of how the law is transformed and how the balance between the stability of legislation and the creativity of action is struck. ${ }^{2}$ Stated briefly, Arendt's concern is to find a way to prevent a majority,

2. As further proof of the inherent difficulty of finding an institutional meaning for civil disobedience, it is interesting to recall John Rawls' remarks: “. . the theory of civil disobedience supplements the purely legal 
even when backed by legal authority, from imposing a dominance that would suffocate any potential contestation. However, in her view dissident movements should not break the consensus universalis, since the right to dissidence would form an integral part of the primary consensus itself and in consequence would only need to be recognized as such by the law. It would not be a question, however, of having popular legitimacy simply prevail over legality; far from promoting a scheme of laws which would be modifiable according to circumstances, in this scenario civil disobedience is instead the legalized reincorporation of the spirit of the law itself.

This interpretation of Arendt's theory becomes clearer if we look more closely at the elements that for Arendt constituted civil disobedience. First, in civil disobedience there must be a disinterested, self-aware and intentional breach of a valid law emanating from a legitimate authority. Secondly, this breach must be made with the cognizance that the law in question should be contravened; thus civil disobedience shows itself to be a political act in the strict sense (Rawls, 1971: 347-352). Lastly, the breach must be public, since it is not the expression of an individual conscience but stems from the beliefs of a group, of an organized minority united by a joint resolution expressing itself in the opposition to a specific government policy, even when this is upheld by the majority (Arendt, 1972a: 55-57).

Subsequently, referring to Socrates and Thoreau, often-cited figures in the theory and practice of civil disobedience, Arendt shows that both took individual decisions, responding only to their own conscience, so that their stances were merely private and essentially apolitical, and did not call into question the relationship between the citizens and the law. Like Socrates, who thought that it was better to suffer a wrong than to inflict one, Thoreau refused to subscribe to an injustice, and while this posture essentially reflected the will to avoid partaking in an injustice which would harm others, it did not primarily concern itself with the wider world in which such abuses exist, nor did it bear upon the consequences that such abuses might have on the future of the world. For this reason Arendt claims that conscience should be substantially political (Arendt, 1972a: 60-61) ${ }^{3}$.

Thus, we can say that Arendt's analysis of civil disobedience is not inscribed either in what we could call the Cartesian tradition, which makes the ego the ontological terrain and sole locus of truth, nor in the American tradition inaugurated by Thoreau. Her aim is not to set a deeply-felt individual freedom against cynical state machinations, but to stress the potential power of a plural form of discussion and debate which does not seek to protect itself from the political, but instead to appropriate the political for itself in order to carry out actions of the widest possible scope. From this perspective, civil disobedience responds to a will to oppose, expressing itself not in particularist impulses but on the basis of a shared judgment which rises up against specific laws or policies held

conception of constitutional democracy. It attempts to formulate the ground upon which legitimate democratic authority may be dissented from in ways that while admittedly contrary to law nevertheless express a fidelity to law and appeal to the fundamental political principles of a democratic regime. Thus to the legal forms of constitutionalism one may adjoin certain modes of illegal protest that do not violate the aims of a democratic constitution in view of the principles by which such dissent is guided" (Rawls, 1971: 338).

3. On this issue see also Margaret Canovan's observations in Canovan, 1992: 183-184. 
to be against the common interest. It embodies a political project which sets itself against the rejection of political obligations and asserts instead its own preeminence over the law. The constitutive function of the community stems from people's experience and not the power of the institutions: "Ever since the Mayflower Compact was drafted and signed ... voluntary associations have been the specifically American remedy for the failure of institutions, the unreliability of men and the uncertain nature of the future" (Arendt, 1972a: 102). Therefore civil disobedience represents the endeavor of citizens to make real changes, not limiting themselves to simple resistance but rather founding a public sphere whose reach would extend beyond the official political institutions.

Civil disobedience, as Arendt understands it, with her analysis of power and politics, consistently opposes the laws being seen as mere vehicles of authority, as for example Derrida conceives them. The potential reach of civil disobedience aspires towards a type of law which could be described as flexible, as it would both envisage and embrace dissent and controversy; thus the law would not be expressed through violence or require pure and simple obedience, since it would represent a type of authority which, in Arendt's scheme, is based on recognition and respect from those exercising it towards those bestowing it. Echoing Jefferson, Arendt claims that we should have the courage not to make constitutions immutable, but instead equip them with clauses making amendments possible (Arendt, 1963: 222-223). Clearly, this position is related to the foundational act itself, which, based on people's collective decision-making, should refuse to appeal to divinity, self-evident truths or natural law since these are irresistible in the strict sense of the word. For Arendt, in politics the appeal to the absolute is illegitimate since it cannot be resisted and therefore involves mere obedience rather than consent and agreement. Arendt's aim, therefore, is to prevent any supreme law being placed above humanity itself, thereby becoming irresistible (Honig, 1991: 97-113). This type of foundation is based on the absolute results of a passive attitude typified by a flight from the present; and we have tragic experiences of this in the 2oth century. Barring an appeal to the absolute in the foundation also prevents any violence aimed at securing and maintaining the new venture (for example in the cases of Robespierre and the Leninist and Stalinist terrors, see Arendt, 1963: 64-79) being transformed into what Benjamin calls "the law preserving administrative violence, that serves it" (Benjamin, 2002: 252). Civil disobedience, according to Arendt, is therefore a tool of the struggle against the force of the law when the latter is not inserted within the sphere of power, as she interprets it.

\section{The Transmission of the Revolutionary Spirit}

Political abuses in the United States during the 1960s and 1970s were unmasked by the intervention of the unforeseen, represented by civil disobedience. This unforeseen element, which for the moment saved the US Republic, was in Arendt's view the direct heir of the American revolutionary tradition. The demonstrations of the human rights movement, the gradual abolition of the racial segregation laws in the southern states, the struggle against the Vietnam war, and the student movement were all described by Arendt in the 
same terms she used to analyze the revolutionary process. American youth seemed to have rediscovered a taste for politics in those years, showing great courage, an unexpected will to act, and an unshakable faith in the possibility of change (Leibovici, 2000: 234). Their many acts of civil disobedience against the government expressed a deep loyalty to the spirit of the revolution and the American Constitution: in the demonstrations in the capital or in the southern states (often semi-improvised and totally lacking any utilitarian or monetary stakes) and in the student protests against the war, Arendt saw the embodiment of the tradition which had inspired the fathers of the Constitution:

For Americans still regard associations as "the only means they have for acting," and rightly so. The last few years, with the mass demonstrations in Washington, often organized on the spur of the moment, have shown to what an unexpected extent the old traditions are still alive. Tocqueville's account could almost be written today: "As soon as several of the inhabitants of United States have taken up an opinion or a feeling which they wish to promote in the world" or have found some fault they wish to correct, "they look out for mutual assistance, and as soon as they have found one another out, they combine. From that moment, they are no longer isolated men but a power seen from afar, whose actions serve for an example and whose language is listened to." It is my contention that civil disobedients are nothing but the latest form of voluntary association, and that they are thus quite in tune with the oldest traditions of the country. (Arendt, 1972a: 95-96)

Arendt, in fact, argues that the revolutionary spirit is inspired by three basic principles: public freedom, public happiness and public spirit. The revolutionary aspiration consists above all in the creation of a permanent sphere in which people can enjoy public freedom, seen by Arendt as participation in public life and as the power to initiate any new project. This exercise of public liberty gives rise to public happiness, which expresses itself "in the joy of discourse, of legislation, of transacting business, of persuading and being persuaded" (Arendt, 1963: 131). Thus her idea of the public spirit combines the enjoyment of public happiness with the responsibility to preserve the political sphere (Ibid.: 279).

The close affinity between Arendt's view of both the revolutionary spirit and her interpretation of civil disobedience seems, to me, clear. As we have remarked above, Arendt saw civil disobedience as a tool for citizens to assert their public freedoms: thanks to it, they can reassert their right to participate in public life, regardless of the crisis of political institutions. Civil disobedience offers them the chance to bring something new into the world, something which may preserve or innovate, may have the aim of safeguarding stable constitutional norms or making necessary changes (Arendt, 1972a: 75). From this standpoint, citizen's practicing civil disobedience, like revolutionaries, express their willingness to shoulder responsibility for the whole public sphere and the determination to act within it. In her observations on the protest movements of the 1960s and 1970s, Arendt stresses that "what really distinguishes this generation is ... its determination to act, its joy in action," and adds: "This generation discovered what the eighteenth century had 
called 'public happiness', which means that when man takes part in public life he opens up for himself a dimension of human experience that otherwise remains closed to him and that in some way constitutes a part of complete happiness"' (Arendt, 1972d: 202-203). In civil disobedience the determination to act and the joy of acting come together, according to Arendt, in that realization of public happiness which is combined with the public spirit.

The presence of the revolutionary spirit in civil disobedience explains why Arendt calls for an institutionalized space for the latter. Civil disobedience, in fact, directly retrieves the experience of the American Revolutionary councils, seen by her as bodies whose aim was to safeguard the revolutionary spirit. As she writes in On Revolution, Jefferson himself saw as fundamental the division of the land into wards small enough to enable all citizens to participate in person. Recalling Jefferson's struggle to found these "elementary republics," Arendt underlines that they are also the constitutive elements of every $19^{\text {th }}$ - and $20^{\text {th }}$-century revolution. The importance of these organizational forms is that "each time they appeared, they sprang up as the spontaneous organs of the people, not only outside of all revolutionary parties but entirely unexpected by them and their leaders" (Arendt, 1963: 249). But the councils were not taken seriously by the politicians, historians or even the revolutionaries themselves, who did not understand that they were faced with an entirely new form of government, creating a new public space for freedom. In the preface to Between Past and Future Arendt writes:

The history of revolutions - from the summer of 1776 in Philadelphia and the summer of 1789 in Paris to the autumn of 1956 in Budapest - which politically spells out the innermost story of the modern age, could be told in parable form as the tale of an age-old treasure which, under the most varied circumstances, appears abruptly, unexpectedly, and disappears again, under different mysterious circumstances, as though it were a fata morgana. (Arendt, 1968a: 5)

Arendt's call for the institutionalization of civil disobedience, therefore, springs from the fear that this echo of the revolutionary spirit, its lost treasure, should disappear once more. Returning to Jefferson's concerns, Arendt argues that the revolutions did not succeed in guaranteeing a space in which the freedoms gained could be wielded by everyone and not only their representatives. It is just this opportunity to recover the activity of self-expression, debate and decision-making - manifestations of freedom which can overcome the limits of the representative system - which is salvaged by civil disobedience (Arendt, 1963: 234-237).

\section{Conclusions}

In light of our discussion so far, we can conclude that for Arendt civil disobedience is linked to the right to form associations promote a particular stance and reduce the power of the majority, thereby channeling the civic urges of people with differing opinions. Briefly, this is linked to the faculty of judgment, to the ability to withstand and resist op- 
pression or injustice, and the power to choose one's companions and recognize the world as one's own (Birulés, 2007: 238-239). We can argue that civil disobedience reclaims the autonomy of thought and the call for responsibility, and recaptures the initiative of acting and of participating actively - the foundation stones of Arendt's thought — restoring its full potential for transformation. Hannah Arendt's whole career, in fact, can be interpreted as a constant endeavor to theorize reality on the basis of its possibility for transformation, responding to the human desire to fully achieve one's own potential jointly with others in a shared public sphere, and characterized by the desire to play an active role in one's world.

Our discussion has enabled us to see clearly the great potential of Arendt's reflections on civil disobedience in analyzing our own present and positioning ourselves within it. Speaking of civil disobedience she questions ideas such as consensus, participation and the law and calls for new forms of citizenship and consent towards the institutions and the state. These analyses and demands are of crucial importance in tackling the challenges of the 21st century: we cannot speak of new forms of citizenship and consensus, of new spaces for political participation, at a time when our models of governing institutions and the state are going through a deep crisis. To the same extent to which individuals have the power to make new beginnings and to act, they should avoid shunning responsibility for the world they live in. The concepts and demands embodied in civil disobedience revive the principles of public freedom, public happiness and the public spirit embodied in the spirit of the revolution; and through them the representative institutions, currently in crisis, may recover a little of the energy of the revolutionary tradition.

The lost treasure of the revolution may be rediscovered in our own times through civil disobedience, with its drive to bring about change in institutions, in politics and in people's opinions. Arendt was convinced that "the civil disobedient shares with the revolutionary the wish to change the world, and the changes he wishes to accomplish can be drastic indeed" (Arendt, 1972a: 77).

This is the sense in which today we can recover the reading of Arendt's reflections on civil disobedience: in the "dark times" which we are living through, we should avoid the temptation to distance ourselves from politics and retreat into conformism, struggling instead to assert our will to intervene in reality. Thus in Men in Dark Times Arendt recalls that: "Even in the darkest of times we have the right to expect some illumination, and that such illumination may well come less from theories and concepts than from the uncertain, flickering, and often weak light that some men and women, in their lives and their works, will kindle under almost all circumstances and shed over the time span that was given them on earth" (Arendt, 1968b: ix). Her theory of civil disobedience articulates the deep need felt by Hannah Arendt to grapple with the present in order to understand and transform it. It reminds us that by demanding our right to citizenship and by setting out from our relationships with each other we can shape, precisely on the basis of the structures and forms we decide to give these relationships, our conditions in the world we were born into. Taking up again these Arendtian guidelines, therefore, means seizing 
the quest for illumination in every moment and in every circumstance in order to change and better our shared world.

\section{References}

Arendt H. (1951) The Origins of Totalitarianism, New York: Harcourt, Brace \& Co.

Arendt H. (1958) The Human Condition, Chicago: Chicago University Press.

Arendt H. (1963) On Revolution, New York: Viking Press.

Arendt H. (1968a) Between Past and Future: Eight Exercises in Political Thought, New York: Viking Press.

Arendt H. (1968b) Men in Dark Times, New York: Harcourt, Brace \& Co.

Arendt H. (1972a) Civil Disobedience. Crises of the Republic, New York: Harcourt, Brace \& Jovanovich, pp. 49-102.

Arendt H. (1972b) Lying in Politics: Reflections on the Pentagon Papers. Crises of the Republic, New York: Harcourt, Brace \& Jovanovich, pp. 3-47.

Arendt H. (1972c) On Violence. Crises of the Republic, New York: Harcourt, Brace \& Jovanovich, pp. 103-184.

Arendt H. (1972d) Thoughts on Politics and Revolution: A Commentary. Crises of the Republic, New York: Harcourt, Brace \& Jovanovich, pp. 199-233.

Arendt H. (1993) Was ist Politik? Aus dem Nachlass, München: Piper.

Arendt H. (1994) Essays in Understanding 1930-1954: Uncollected and Unpublished Works by Hannah Arendt, New York: Harcourt, Brace \& Co.

Arendt H. (1995) Karl Marx e la tradizione del pensiero politico occidentale. Micromega, no 5, pp. 41-108.

Arendt H. (2002) Denktagebuch, München: Piper.

Arendt H., McCarthy M. (1995) Between Friends: The Correspondence of Hannah Arendt and Mary McCarthy 1949-1975, New York: Harcourt Brace.

Benjamin W. (2002) Critique of Violence. Selected Writings, Vol. 1: 1913-1926, London: Belknap Press, pp. 236-252.

Birulés F. (2007) Una herencia sin testamento: Hannah Arendt, Barcelona: Herder.

Canovan M. (1992) Hannah Arendt: A Reinterpretation of Her Political Thought, Cambridge: Cambridge University Press.

Derrida J. (1997) Force de loi: le fondement mystique de l'autorité, Paris: Galiléé.

Enegrén A. (1994) La pensée politique de Hannah Arendt, Paris: Presses Universitaires de France.

Goldoni M., McCorkindale Ch. (eds.) (2012) Hannah Arendt and the Law, Oxford: Hart. Honig B. (1991) Declarations of Independence: Arendt and Derrida on the Problem of Founding a Republic. American Political Science Review, vol. 85, no 1, pp. 97-113.

Hilb C. (2007) Violencia y política en la obra de Hannah Arendt. Al Margen, no 21-22, pp. 120-149.

Kalyvas A. (2005) Popular Sovereignty, Democracy, and the Constituent Power. Constellations, vol. 12, no 2, pp. 223-244. 
Leibovici M. (2000) Hannah Arendt: la passion de comprendre, Paris: Desclée de Brouwer. Negri A. (1999) Insurgencies: Constituent Power and the Modern State, Minneapolis: University of Minnesota Press.

Pitkin H. F. (1998) The Attack of the Blob: Hannah Arendt's Concept of the Social, Chicago: University of Chicago Press.

Rawls J. (1971) A Theory of Justice, Cambridge: Harvard University Press.

Young-Bruehl E. (2006) Why Arendt Matters, New Haven: Yale University Press.

\section{Трансмиссия революционного духа: размышления Ханны Арендт о гражданском неповиновении}

\section{Стесрания Фантаучци}

$\mathrm{PhD}$, научный сотрудник семинара «Философия и гендер» Барселонского университета

Адрес: Montalegre, 6, Barcelona, Spain 08001

E-mail: stefantauzzi@gmail.com

Целью статьи является рассмотрение анализа гражданского неповиновения в работах Ханны Арендт. Этот аспект философии Арендт представляет собой мощное побуждение к позитивному и осмысленному взгляду на мир, в котором мы живем. Отталкиваясь от этого утверждения, автор начинает с анализа идеи Арендт о законе, обсуждает ее отношенческое измерение и связь с consensus universalis (всеобщее согласие), понимаемое как осознанная и искренняя верность законам страны. Учитывая эти два момента, в дальнейшем рассматривается предложение Арендт, изложенное в эссе «Гражданское неповиновение», суть которого состоит в формировании духа закона совместимого с гражданским неповиновением. Представление о том, что гражданское неповиновение не противоречит духу закона, говорит о том, что Арендт признавала конститутивную функцию сообщества, в котором индивиды определяют себя в отношениях с другими, опираясь на тот тип справедливости, который возникает от столкновения различных мнений. С этой точки зрения дается объяснение, как гражданское неповиновение позволяет гражданам утверждать свою публичную свободу и тем самым вносить в мир нечто новое, демонстрировать свою ответственность. Таким образом, по Арендт, гражданское неповиновение заново устанавливает (в том числе поддерживаемое революционным духом) пространство постоянного участия в публичной жизни: общую арену для наслаждения публичным счастьем.

Ключевые слова: Ханна Арендт, гражданское неповиновение, революция, всеобщее согласие, закон, трансмиссия 